\title{
Proteinase Activity in Rumen Ciliate Protozoa
}

\author{
By BARBARA C. LOCKWOOD, ${ }^{*}$ GRAHAM H. COOMBS ${ }^{1}$ AND \\ ALAN G. WILLIAMS ${ }^{2}$ \\ ${ }^{1}$ Department of Zoology, University of Glasgow, Glasgow G12 8QQ,UK \\ ${ }^{2}$ Hannah Research Institute, Ayr KA6 5HL, UK
}

(Received 14 March 1988; revised 19 April 1988)

\begin{abstract}
Azocasein-degrading proteinase activity was detected in all rumen ciliate protozoa that were examined from four entodiniomorphid and two holotrich genera. All of the activities were optimal in the range $\mathrm{pH} 4 \cdot 0-5 \cdot 0$ and were inhibited by cysteine proteinase inhibitors, notably leupeptin. The inhibition profiles and extent of inhibition observed with the different groups of inhibitors were organism-specific. Gelatin-SDS-polyacrylamide gel electrophoresis of protozoal lysates revealed multiple forms of the proteinases in the species examined. The number of enzymes detected, their molecular masses, the level of activity and inhibitor susceptibility was genus-dependent. The proteinase profiles of the two holotrich species differed and inter-species differences were also apparent among species of the genus Entodinium. The characteristics and molecular size distribution of rumen bacterial proteinases were different to the protozoal proteinases. Low levels of proteinase activity, of apparently bacterial origin, were detected by gelatin-SDS-PAGE analysis of cell-free rumen liquor.
\end{abstract}

\section{INTRODUCTION}

The degradative activities of the rumen microbial population adversely affect the availability of dietary protein to the host ruminant. The proteolytic bacteria are mainly involved in the degradation of plant protein (Nugent \& Mangan, 1981), whereas the rumen ciliate protozoa are thought to degrade bacterial and insoluble particulate proteins (Hino \& Russell, 1987; Wallace et al., 1987). The predation of the bacteria by ciliates increases the rate of bacterial protein turnover (Wallace \& McPherson, 1987) and decreases the efficiency of bacterial growth in the rumen (Veira, 1986), and defaunation (i.e. elimination of protozoa from the rumen) of animals receiving low protein diets has resulted in enhanced animal productivity and wool growth (Bird \& Leng, 1983, 1984). Nevertheless, despite the apparent ecological and economic importance of protozoal proteolysis, the proteolytic enzymes of the rumen ciliates have not been well characterized.

The studies undertaken to date that demonstrate protozoal proteolysis have either compared protein breakdown in faunated and ciliate-free rumen contents (Shinchi et al., 1986; Wallace \& McPherson, 1987; Wallace et al., 1987) or have used washed suspensions of mixed populations of protozoa, that contained both holotrich and entodiniomorphid ciliates, to examine proteolysis (Onodera \& Kandatsu, 1970; Forsberg et al., 1984) and amino acid metabolism (Williams, 1986). Some properties of the intracellular (Brock et al., 1982; Forsberg et al., 1984) and extracellular (Shinchi \& Kandatsu, 1980, 1981, 1983) proteinases present in mixed ciliate populations have also been described. Information on the proteinases of individual species of protozoa is, however, very limited. Proteolysis has been demonstrated in representative species from eight genera of rumen entodiniomorphid ciliates, isolated directly from the rumen or

\footnotetext{
Abbreviations: TLCK, $N \alpha$-p-tosyl-L-lysine chloromethyl ketone; TPCK, $N$-tosyl-L-phenylalanine chloromethyl ketone; PMSF, phenylmethylsulphonyl fluoride.
} 
grown in vitro (Abou Akkada \& Howard, 1962; Naga \& El-Shazly, 1968; Coleman, 1983), although only with Entodinium caudatum have the enzymes involved been studied (Abou Akkada \& Howard, 1962; Coleman, 1983). Here we describe the characteristics of the proteinases present in ciliate protozoa from both holotrich and entodiniomorphid genera.

\section{METHODS}

Preparation of protozoal suspensions. The protozoal species studied were all recovered directly from ovine rumen contents that had been withdrawn $2 \mathrm{~h}$ after the ration had been consumed. Dasytricha ruminantium, Ophryoscolex caudatus and Isotricha spp. were isolated by filtration from the rumen ciliate population of two animals receiving a diet of molassed sugar beet pulp $\left(600 \mathrm{~g} \mathrm{~d}^{-1}\right)$ and hay $\left(300 \mathrm{~g} \mathrm{~d}^{-1}\right)$ as previously described (Williams \& Yarlett, 1982). The $O$. caudatus preparation was collected on a $55 \mu \mathrm{m}$ porosity filter after an initial pre-filtration $(64 \mu \mathrm{m}$ porosity cloth) to remove all the large and most of the intermediate sized protozoa. The protozoa retained by the $55 \mu \mathrm{m}$ porosity filter were repeatedly resuspended in sterile salts solution $\mathrm{D}$ (Coleman, 1978) and allowed to stand for $2-3 \mathrm{~min}$ at $39^{\circ} \mathrm{C}$, resulting in the differential sedimentation of $O$. caudatus and Isotricha spp. Contaminating Isotricha spp. were lysed by incubation at $39^{\circ} \mathrm{C}$ for $60 \mathrm{~min}$ in salts solution $\mathrm{D}$ containing mannose $\left(10 \mathrm{mg} \mathrm{ml}^{-1}\right)$. The subsequent cell preparation was washed thoroughly with sterile salts solution on a $30 \mu \mathrm{m}$ filter. This resulted in a single-species preparation of $O$. caudatus as described by Ogimoto \& Imai (1981).

Epidinium caudatum ecaudatum/Entodinium simplex and Polyplastron multivesiculatum/Entodinium spp., originally isolated from rumen contents and kindly supplied as cultures by $\mathrm{Dr} \mathrm{G}$. S. Coleman, were present as cocultures in animals receiving a daily diet of hay $(500 \mathrm{~g}$ ) and goat mix (a commercially compounded feed containing rolled barley, rolled oats, wheat feed, soya bean, flaked maize and minerals; $500 \mathrm{~g}$ ). The co-cultures were the only protozoa present and had been introduced into, and established in, the ruminal contents of ciliate-free (defaunated) animals. The protozoa were readily separable, without any cross-contamination, by differential filtration and were collected on defined aperture textiles of the appropriate porosity following pre-filtration through a $100 \mu \mathrm{m}$ porosity filter cloth (Ep. caudatum ecaudatum $30 \mu \mathrm{m} ;$ En. simplex $15 \mu \mathrm{m} ; P$. multivesiculatum $40 \mu \mathrm{m}$; mixed entodinia $15 \mu \mathrm{m}$ ). The larger protozoa were washed thoroughly on a $30 \mu \mathrm{m}$ porosity filter; En. simplex and the mixed Entodinium spp. preparations were washed five times by resuspension in sterile salts solution $\mathrm{D}$ and recovered by centrifugation $(500 \mathrm{~g}, 1 \mathrm{~min}$, room temperature). Anaerobiosis was maintained during the isolation procedures and the filter-sterilized $(0.45 \mu \mathrm{m}$ filter $)$ salts solution was deoxygenated by autoclaving and gassing with $\mathrm{N}_{2}$ and pre-warmed to $39^{\circ} \mathrm{C}$ prior to use as previously described (Williams \& Yarlett, 1982). The washed protozoal suspensions were sedimented by centrifugation $(500 \mathrm{~g}, 1 \mathrm{~min}$, room temperature) and resuspended in sterile deoxygenated distilled water. The contamination of the preparations by other species of protozoa was negligible $(<1 \%)$ (Williams \& Yarlett, 1982). All protozoal preparations were extensively washed with sterile buffered salts solution to ensure complete removal of free bacteria and also to minimize contamination of the protozoa by adherent and ingested bacteria. Since some bacteria may have been present in all the preparations, and so bacterial enzymes could have contributed to the proteinase activity detected in the protozoal preparations, control experiments on a population of mixed rumen bacteria were undertaken.

Mixed rumen bacteria were prepared from the rumen contents, withdrawn $2 \mathrm{~h}$ after feeding, from a sheep receiving the hay and goat mix ration. The rumen contents were initially filtered through cheesecloth to remove the large particulate material and were pre-centrifuged $\left(1000 \mathrm{~g}, 10 \mathrm{~min}, 4^{\circ} \mathrm{C}\right)$ to remove the protozoa and small particulate debris. The supernatant material was carefully decanted and centrifuged $\left(38000 \mathrm{~g}, 30 \mathrm{~min}, 4^{\circ} \mathrm{C}\right)$ to sediment the bacteria. The supernatant was taken as the cell-free rumen liquor fraction. The bacterial cell pellet was resuspended by homogenization in sterile deoxygenated distilled water.

The samples were stored at $-20^{\circ} \mathrm{C}$ in screw-capped ampoules with a $\mathrm{N}_{2}$ headspace. Prior to use, Triton X-100 was added to $0.25 \%(\mathrm{v} / \mathrm{v})$, which resulted in the complete lysis of the protozoa as judged by microscopic observation. The lysates were centrifuged $(10000 \mathrm{~g}, 5 \mathrm{~min}$, room temperature) and the supernatants used for the enzyme analyses.

Proteinase assays. Proteinase activity was assayed using azocasein as the substrate as previously described (Coombs, 1982). Assays were done at $39^{\circ} \mathrm{C}$ in duplicate or triplicate. An increase of 1 absorbance unit was caused by the hydrolysis of $0.4 \mathrm{mg}$ azocasein under the reaction conditions stated. Buffers used were $0 \cdot 1 \mathrm{M}$-glycine/ $\mathrm{HCl}$ (pH 3.0), $0 \cdot 1 \mathrm{M}$-sodium acetate/acetic acid (pH 3.5-5.5) and 0.1 M-sodium phosphate ( $\mathrm{pH} 6 \cdot 0$ ).

Protein concentration was determined by the method of Sedmak \& Grossberg (1977) using bovine serum albumin as standard.

The effect of proteinase inhibitors was tested by the addition to cell lysates of pepstatin and leupeptin at a final concentration of $100 \mu \mathrm{g} \mathrm{ml}^{-1}$ and $N \alpha$-p-tosyl-L-lysine chloromethyl ketone (TLCK), $N$-tosyl-L-phenylalanine chloromethyl ketone (TPCK), phenylmethylsulphonyl fluoride (PMSF), 1,10-phenanthroline and iodoacetic acid at a final concentration of $1 \mathrm{mM}$. The lysates were then incubated at room temperature for $1 \mathrm{~h}$ prior to assaying for proteinase activity at the optimum $\mathrm{pH}$. Pepstatin and TPCK were dissolved in $5 \%(\mathrm{v} / \mathrm{v})$ dimethylsulphoxide 
(DMSO), PMSF was dissolved in ethanol and the remaining inhibitors were dissolved in water. Controls, preincubated and assayed without inhibitor but with water, ethanol or DMSO, were done as appropriate.

Gelatin-SDS-PAGE. Analysis of the proteinases of protozoal lysates was done by gelatin-SDS-PAGE (Lockwood et al., 1987). The acrylamide concentration of the separating gel was $7.5 \%(\mathrm{w} / \mathrm{v})$ and electrophoresis was done at $6 \mathrm{~mA}$ per gel $(175 \mathrm{~mm} \times 140 \mathrm{~mm}, 1.5 \mathrm{~mm}$ thick $)$ overnight. The proteinase bands were developed in $0.1 \mathrm{M}$-sodium acetate/acetic acid buffer pH 5.0 containing $1 \mathrm{~mm}$-dithiothreitol (DTT) for $4 \mathrm{~h}$ at $39^{\circ} \mathrm{C}$. The bands were visualized by staining with PAGE blue 83 and destaining as previously described (Lockwood et al., 1987). Molecular masses of individual proteinases were determined from the mobility of protein standards. The mobility of these standards was not affected by the presence of gelatin.

The effect of inhibitors on the proteinases was tested by the addition of leupeptin and pepstatin at $20 \mu \mathrm{g} \mathrm{ml}^{-1}$ and iodoacetic acid, PMSF, and 1,10-phenanthroline at $1 \mathrm{mM}$ to the incubation buffer.

Materials. Iodoacetic acid, TLCK, TPCK, 1,10-phenanthroline, DTT, azocasein, gelatin (type A: from porcine skin, approx. 300 Bloom), leupeptin and pepstatin were obtained from Sigma. PMSF was supplied by Boehringer. All other reagents were AnalaR grade and obtained from BDH. The defined aperture textiles were obtained from Henry Simon Ltd, Stockport.

\section{RESULTS}

Proteinase activity towards azocasein was detected in cell lysates of all the protozoa investigated, although at different levels. Relatively low activities were detected in Isotricha spp. whereas the levels were higher in the putatively closely-related $D$. ruminantium. Activities in the entodiniomorphic species ranged from $2.4 \mu \mathrm{g}$ azocasein hydrolysed $\mathrm{min}^{-1}$ (mg protein) ${ }^{-1}$ in O. caudatus to $12.0 \mu \mathrm{g}$ azocasein hydrolysed $\mathrm{min}^{-1}$ (mg protein) ${ }^{-1}$ in $E$. simplex (Fig. 1). All of the activities were optimal at acidic $\mathrm{pH}$ in the range 4.0-4.5 (Fig. 1) and some were markedly stimulated by the addition of $1 \mathrm{mM}$-DTT although it had no significant effect on the activity detected in $O$. caudatus (Table 1). The proteinase activities of all species were inhibited by cysteine proteinase inhibitors, notably leupeptin, but were relatively unaffected by inhibitors of other classes of proteinase (Table 1).

Azocasein-hydrolysing activity was also detected in rumen bacteria. The activity differed, however, from that found in the protozoa in that it was maximal $[6.9 \mu \mathrm{g}$ azocasein hydrolysed $\min ^{-1}(\mathrm{mg} \text { protein })^{-1}$ ] at a higher $\mathrm{pH}(5 \cdot 0)$, had considerable activity at $\mathrm{pH} 6.0$ and was apparently unaffected by $1 \mathrm{mM}$-DTT (Table 1 ). The inhibition profile of the bacterial activity (Table 1) showed that it was less affected by inhibitors of cysteine proteinases. No activity towards azocasein was detected (limit of detection, $0.01 \mu \mathrm{g}$ azocasein hydrolysed $\mathrm{min}^{-1}$ ) in the extracellular rumen liquor, although low levels of high molecular mass activity were detected by gelatin-SDS-PAGE analysis.

Analysis of the proteolytic enzymes by gelatin-SDS-PAGE revealed multiple forms of proteinase present in the lysates of each of the rumen ciliates. The proteinase band patterns obtained with the various species differed with respect to the number of enzymes, their molecular masses and the level of activity detected (Figs 2, 3 and 4).

Some similarities were apparent in the proteinases of the holotrich species. Both were found to have a number of high molecular mass proteinases and a single major low molecular mass band. However, the molecular masses of the enzymes in the two species differed appreciably; there were also distinct differences between the minor, less active bands detected (Fig. 2) and in inhibitor sensitivity. Whereas all the bands detected with $D$. ruminantium were sensitive to leupeptin, iodoacetic acid and 1,10-phenanthroline, with Isotricha spp. only the low molecular mass band $(F)$ was inhibited by the cysteine proteinase inhibitors, although the high molecular mass enzymes were sensitive to 1,10-phenanthroline.

Comparison of the proteinases detected in En. simplex with those found in a mixed Entodinium population showed that the major bands apparent in the mixed population do not correlate with those detected in En. simplex, although there were a number of minor bands in the mixed preparation that had similar molecular masses to those of the major enzymes found in the single species (Fig. $3 a, b$ ).

There was some indication of differences in substrate specificities of some of the enzymes. Although relatively low proteinase activity towards azocasein was detected in $O$. caudatus, a number of bands of activity could be detected on the gels (Fig. $3 c$ ). In contrast, although 


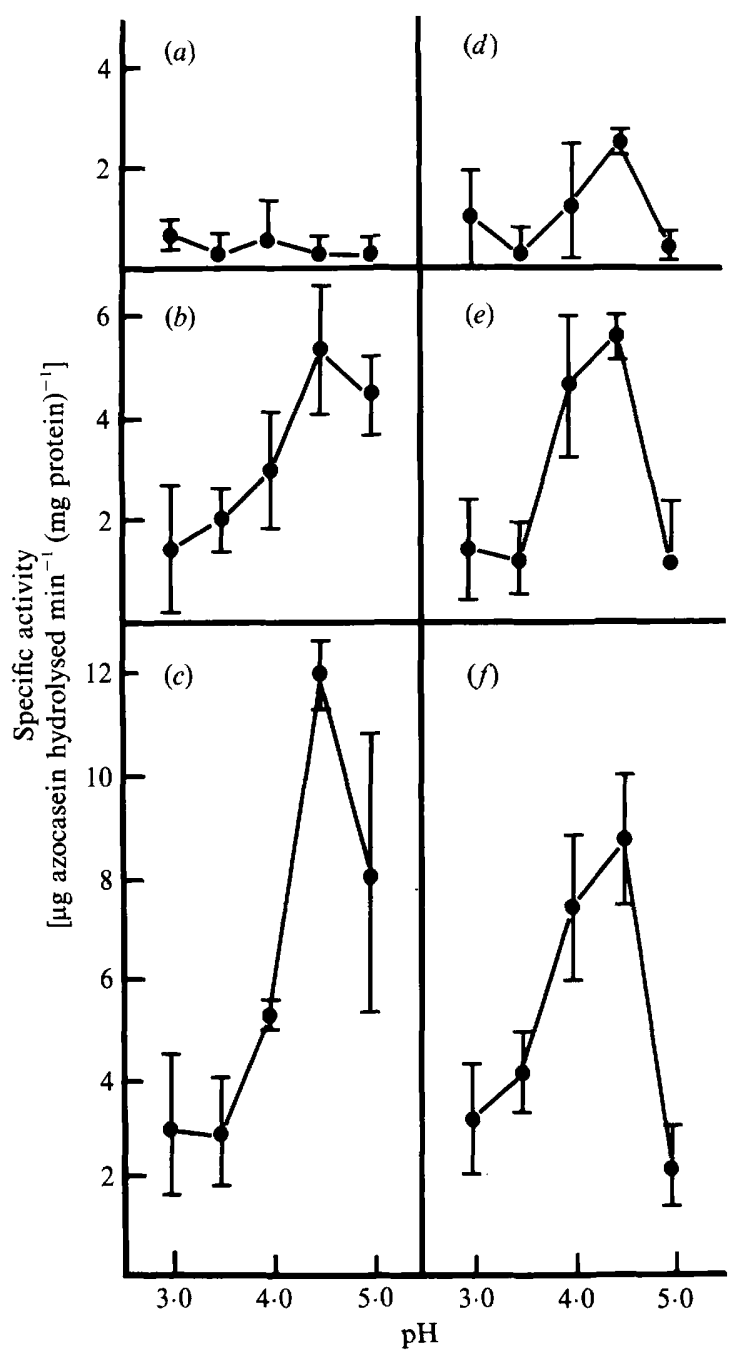

Fig. 1. pH profiles of the azocasein-degrading proteinase activities in rumen ciliates. (a) Isotricha spp.; (b) D. ruminantium; (c) En. simplex; (d)O. caudatus; $(e) P$. multivesiculatum; $(f)$ Ep. caudatum ecaudatum. The error bars represent the SD values of the means from the number of experiments described in Table 1.

P. multivesiculatum had relatively high levels of azocasein-hydrolysing activity, only low activity bands were observed using gelatin gels (Fig. $3 d$ ).

All of the proteinase activities detected in En. simplex and $O$. caudatus were sensitive to the cysteine proteinase inhibitors leupeptin and iodoacetic acid and also to 1,10-phenanthroline but were unaffected by PMSF or pepstatin. The inhibitor sensitivities of the bands detected with $P$. multivesiculatum were not fully studied, although band A was shown to be sensitive to the cysteine proteinase inhibitors but not to 1,10 -phenanthroline.

Controls of rumen bacteria and extracellular rumen liquor demonstrated that the proteinases detected were indeed of protozoal origin and not due to contaminating bacteria. The only proteinase bands apparent for the bacterial samples on the gelatin gels were of very high molecular mass and of relatively low activity. No bands that correlated with the lower molecular mass protozoal enzymes were detected (Fig. 4). Only very low activity bands of high molecular mass were detected in the extracellular rumen liquor, with molecular masses similar to the bacterial enzymes. There was no evidence for extracellular proteinases of protozoal origin. 


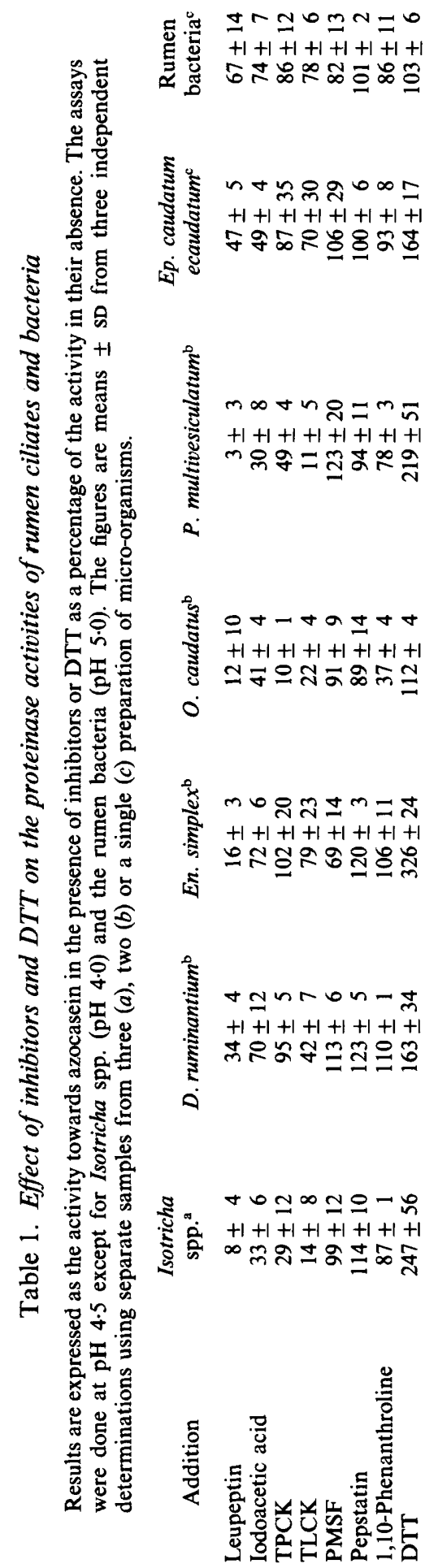





Fig. 2. The proteinases of rumen holotrich ciliates detected using gelatin-SDS-PAGE. (a) Isotricha spp., track 1, $100 \mu \mathrm{g}$ protein; track $2,50 \mu \mathrm{g}$ protein. (b) $D$. ruminantium, $25 \mu \mathrm{g}$ protein. The positions of the molecular mass markers are indicated by the arrows; the major ciliate proteinases detected are labelled A-F.

\section{DISCUSSION}

The ability of rumen protozoa to transform both dietary and microbial proteins can markedly affect the supply of nitrogen to the host ruminant. All of the entodiniomorphid ciliates examined by Coleman (1983) were able to degrade fraction 1 leaf protein (ribulose 1,5-bisphosphate carboxylase). Different protein substrates were used in the survey reported here and their use confirmed that the entodiniomorphid protozoa $P$. multivesiculatum, O. caudatus, Ep. caudatum ecaudatum and En. simplex possess proteolytic enzymes. This study has also demonstrated, for the first time, that proteinases are present in the rumen holotrich ciliate $D$. ruminantium and a mixed preparation of Isotricha prostoma and Isotricha intestinalis. Multiple forms of proteinase were shown to be present in both protozoal groups although the activities towards azocasein were generally higher in the entodiniomorphs. Our results concerning $\mathrm{pH}$ optima, inhibitor susceptibility and stimulation by DTT are, in the main, consistent with the majority of the findings of previous studies (Abou Akkada \& Howard, 1962; Coleman, 1983; Shinchi \& Kandatsu, 1983; Forsberg et al., 1984) and indicate that cysteine proteinases are present in all six genera examined, although their contribution to overall proteolysis appears to differ with species. Bacteria were included in this study simply as a control to take into account the possible contribution to proteolysis of the bacteria associated with the purified protozoa. Our results, however, confirm the many previous reports that the bacteria contain proteinases. Our inability to detect proteolytic activity in rumen liquor contrasts with the reports of others (Brock et al., 1982; Kopecny \& Wallace, 1982) but probably reflects the use of different substrates as we confirmed the presence of cell-free enzymes using gelatin-SDS-PAGE.

The use of gelatin-SDS-PAGE revealed marked differences between species with respect to the numbers and molecular masses of proteinases present in the protozoal lysates. This 
(a)

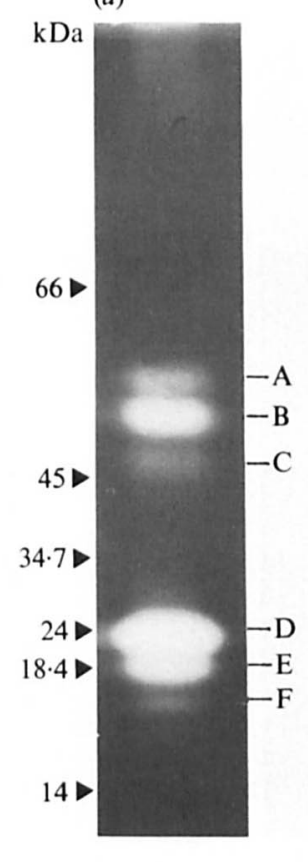

(c)

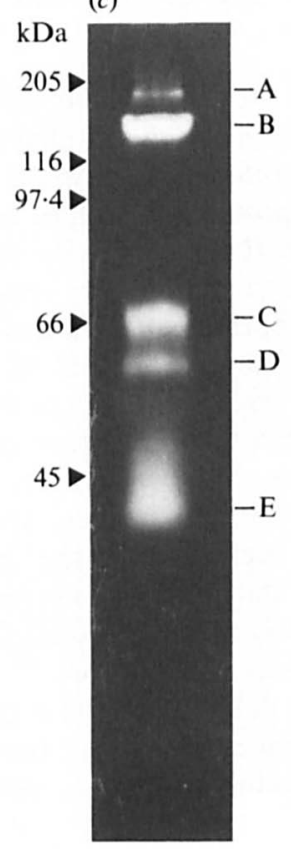



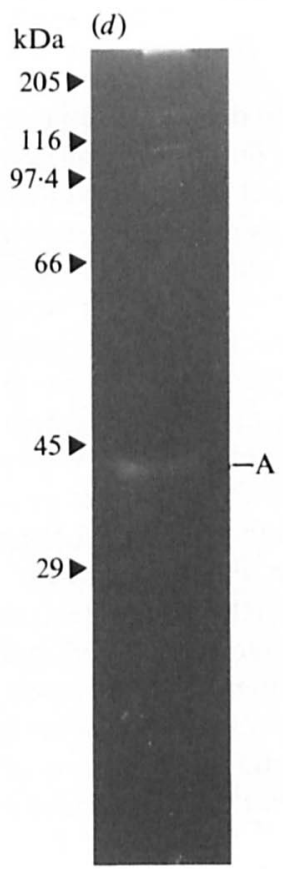

Fig. 3. The proteinases of rumen entodiniomorphic ciliates detected using gelatin-SDS-PAGE. (a) En. simplex, $10 \mu \mathrm{g}$ protein. (b) Entodinium spp., track 1, $25 \mu \mathrm{g}$ protein; track 2, $10 \mu \mathrm{g}$ protein. (c) $O$. caudatus, $100 \mu \mathrm{g}$ protein. (d) P. multivesiculatum, $100 \mu \mathrm{g}$ protein. The positions of the molecular mass markers are indicated by the arrows; the major ciliate proteinases detected are labelled A-P. 


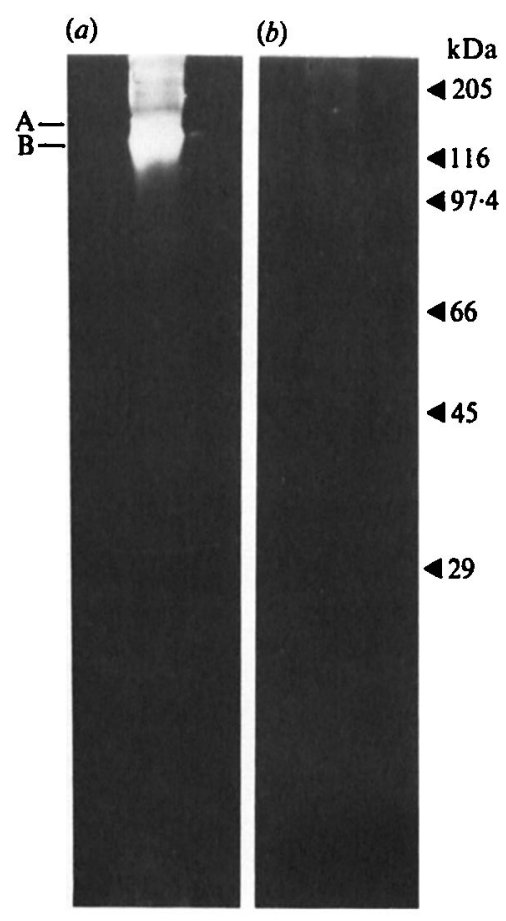

Fig. 4. The proteinases of rumen bacteria and in extracellular rumen liquor detected by gelatin-SDSPAGE. (a) Rumen bacteria, $75 \mu \mathrm{g}$ protein. (b) Rumen liquor, $50 \mu \mathrm{l}$. The positions of the molecular mass markers are indicated by the arrows; the major proteinases detected are labelled $\mathbf{A}$ and $\mathbf{B}$.

technique has also been used to detect and characterize the extracellular serine proteinases of a strain of the rumen bacterium Butyrivibrio fibrisolvens (Strydom et al., 1986) and to facilitate the study of the proteinases present in other non-rumen protozoa (Lockwood et al., 1987). Most interesting were the differences detected between the proteinase profiles of the two holotrich preparations; the individual enzymes also differed in their sensitivity to inhibitors. Thus, although the metabolic characteristics of the two genera are apparently very similar (Williams, 1986), there are clear differences between the species in both the proteinases and carbohydrases (Williams, 1986) present. Further biochemical studies may well reveal other differences.

Inter-species differences in the proteinases present within the genus Entodinium are also apparent. The results presented here show that a mixed preparation of Entodinium spp. possessed several electrophoretically distinct proteinases that were not present in En. simplex lysates. In both this study and that of Coleman (1983), the highest specific activities of proteinase among the rumen ciliate protozoa were measured in the Entodinium isolates examined. This suggests that further characterization of the proteinases present in the principal species of rumen entodinia would be justified, particularly as the protozoa from this genus are normally numerically predominant in the rumen protozoal population.

The characteristics of the protozoal proteinases are different to those described for other rumen micro-organisms. The major proteinase of the anaerobic rumen fungus Neocallimastix frontalis has been reported to be a high molecular mass metalloproteinase with maximal activity at pH 7.5 (Wallace \& Joblin, 1985). The bacteria possess cysteine, serine, aspartic and metalloproteinases (Hazlewood \& Edwards, 1981; Brock et al., 1982; Kopecny \& Wallace, 1982). The predominant proteolytic enzymes of the rumen bacteria are cysteine proteinases with broad $\mathrm{pH}$ optima that are associated with, and easily removed from, the complex surface layers of the bacteria. We confirmed that the bacteria possess proteinases that are active over a broad $\mathrm{pH}$ range although our finding that the activity was optimal at $\mathrm{pH} 5.0$ differs a little from some previous reports (Kopecny \& Wallace, 1982). This probably reflects the use of different 
substrates. It is clear, however both from this and from other studies (Brock et al., 1982; Kopecny \& Wallace, 1982; Forsberg et al., 1984) that the inhibition profiles of the bacterial and protozoal enzymes differ in various ways. Notably we found that the bacterial activity was largely unaffected by DTT and inhibitors that characteristically inhibit cysteine proteinases. As other inhibitors were also ineffective our results do not allow us to comment further on the types of proteinase present in bacteria. Gelatin-SDS-PAGE analysis has also demonstrated that whereas the protozoal lysates typically contained lower molecular mass enzymes, no corresponding bands were present in the bacterial preparation. Measurements of proteolytic activity indicate that the rumen bacterial population has more overall activity than the protozoal fraction (Brock et al., 1982; Wallace et al., 1987). The protozoa, however, possess a very different array of proteolytic enzymes with largely undefined substrate specificities and function. Further studies are required to establish the role and contribution to proteolysis of the proteinases of the various groups of micro-organisms in the rumen.

Carbohydrate-degrading and bacteriolytic enzymes have been detected in cell-free culture supernatants of certain rumen protozoa following incubation in vitro (Williams, 1986). Shinchi \& Kandatsu (1980) were also able to detect proteolytic enzymes in the incubation supernatants of mixed rumen protozoa and subsequently examined the properties of the extracellular activity (Shinchi \& Kandatsu, 1981; 1983). They also observed that the proteolytic activity of cell-free rumen contents from defaunated animals was lower than that from conventionally faunated ruminants (Shinchi et al., 1983) and concluded that the rumen protozoa secreted proteolytic enzymes in the rumen. However, in the present work only high molecular mass proteinases were detected in cell-free rumen liquor. The molecular size distribution was similar to that of the rumen bacterial proteinases and no lower molecular mass, protozoal enzymes were observed. Thus our studies refute a role for secretory protozoal proteinases, although it is possible that cellfree enzymes may have been inactivated during processing whereas they could retain activity for some time in the rumen digesta. A contribution of such enzymes to the overall digestion in the rumen cannot yet be fully discounted.

A more detailed understanding of the rumen protozoal proteinases and their effects is therefore required if improvements in the efficiency of nitrogen utilization in the rumen are to be gained. Further information on these enzymes may allow their detrimental activities to be selectively controlled without recourse to defaunation as this procedure, at present, is not suitable for on-farm usage and does not always achieve improvements in animal productivity as the protozoa are advantageous in other metabolic areas.

Thanks are due to Dr G. S. Coleman for providing the cultures of En. simplex, P. multivesiculatum and Ep. caudatum ecaudatum which were used to establish in vivo cultures. We also acknowledge the assistance of $\mathrm{Mr}$ Graham Pollock in carrying out several of the assays.

\section{REFERENCES}

Abou Akkada, A. R. \& Howard, B. H. (1962). The biochemistry of rumen protozoa. 5 . The nitrogen metabolism of Entodinium. Biochemical Journal 82, 313-320.

BIRD, S. H. \& LENG, R. A. (1983). The influence of the absence of rumen protozoa on ruminant production. In Recent Advances in Animal Production in Australia, pp 110-115. Edited by D. J. Farrell \& P. Vohra. Armidale, Australia: University of New England Publishing Unit.

BIRD, S. H. \& LENG, R. A. (1984). Further studies on the effect of the presence or absence of protozoa in the rumen on live-weight gain and wool growth of sheep. British Journal of Nutrition 52, 607-611.

Brock, E. M., Forsberg, C. W. \& BuCHANAN-SMITH, J. G. (1982). Proteolytic activity of rumen microorganisms and effects of proteinase inhibitors. Applied and Environmental Microbiology 44, 561-569.
Coleman, G. S. (1978). Rumen entodiniomorphid protozoa. In Methods of Cultivating Parasites in vitro, pp. 39-54. Edited by A. E. R. Taylor \& J. R. Baker. London, New York: Academic Press.

Coleman, G. S. (1983). Hydrolysis of Fraction 1 leaf protein and casein by rumen entodiniomorphid protozoa. Journal of Applied Bacteriology 55, 111-118.

Coombs, G. H. (1982). Proteinases of Leishmania mexicana and other flagellate protozoa. Parasitology 84, 149-155.

Forsberg, C. W., Lovelock, L. K. A., Krumholz, L. \& Buchanan-Smith, J. G. (1984). Protease activities of rumen protozoa. Applied and Environmental Microbiology 43, 1026-1033.

Hazlewood, G. P. \& Edwards, R. (1981). Proteolytic activities of a rumen bacterium, Bacteroides ruminicola R8/4. Journal of General Microbiology 125, 1115. 
Hino, T. \& Russell, J. B. (1987). Relative contributions of ruminal bacteria and protozoa to degradation of protein in vitro. Journal of Animal Science 64, 261-270.

KOPECNY, J. \& Wallace, R. J. (1982). Cellular location and some properties of proteolytic enzymes of rumen bacteria. Applied and Environmental Microbiology 43, 1026-1033.

LOCKWOOD, B. C., NORTH, M. J., SCOTT, K. I., BREMNER, A. F. \& CoOMBS, G. H. (1987). The use of a highly sensitive electrophoretic method to compare the proteinases of trichomonads. Molecular and Biochemical Parasitology 24, 89-95.

NaGa, M. A. \& El-Shazly, K. (1968). The metabolic characterization of the ciliate protozoon Eudiplodinium medium from the rumen of buffalo. Journal of General Microbiology 53, 305-315.

Nugent, J. H. A. \& Mangan, J. L. (1981). Characteristics of the rumen proteolysis of Fraction 1 (18 S) leaf protein from lucerne (Medicago sativa $\mathrm{L}$.). British Journal of Nutrition 46, 39-58.

Ogimoto, K. \& ImaI, S. (1981). Atlas of Rumen Microbiology. Tokyo: Japanese Scientific Society Press.

Onodera, R. \& Kandatsu, M. (1970). Amino acids and protein metabolism of rumen ciliate protozoa. IV. Metabolism of casein. Japanese Journal of Zootechnical Science 41, 307-313.

Sedmak, J. J. \& Grossberg, S. E. (1977). A rapid sensitive and versatile assay for protein using Coomassie brilliant blue G250. Analytical Biochemistry 79, 544-552.

SHINCHI, S. \& KANDATSU, M. (1980). Extracellular proteolytic activity of rumen ciliate protozoa. 1. Proteolytic activity of cell-free rumen liquid, incubation medium of rumen ciliate protozoa and their extracts. Bulletin of Azabu University Veterinary Medicine 1, 47-53.
Shinchi, S. \& Kandatsu, M. (1981). On some properties of extra- and intracellular proteolytic activity of rumen ciliate protozoa. Japanese Journal of Zootechnical Science 52, 861-868.

ShINCHI, S. \& Kandatsu, M. (1983). On some properties of extracellular proteolytic activity of rumen ciliate protozoa. Japanese Journal of Zootechnical Science 54, 290-296.

ShINCHI, S., ITOH, T., ABE, M. \& Kandatsu, M. (1986). Effect of rumen ciliate protozoa on the proteolytic activity of cell-free rumen liquid. Japanese Journal of Zootechnical Science 57, 89-96.

STRYdom, E., Mackie, R. I. \& Woods, D. R. (1986). Detection and characterization of extracellular proteases in Butyrivibrio fibrisolvens H17c. Applied Microbial Biotechnology 24, 214-217.

VEIRA, D. M. (1986). The role of the ciliate protozoa in nutrition of the ruminant. Journal of Animal Science 63, 1547-1560.

Wallace, R. J. \& Joblin, K. N. (1985). Proteolytic activity of a rumen anaerobic fungus. FEMS Microbiology Letters 29, 19-25.

Wallace. R. J. \& MCPherson, C. A. (1987). Factors affecting the rate of breakdown of bacterial protein in rumen fluid. British Journal of Nutrition 58, 313323.

Wallace, R. J., Broderick, G. A. \& Brammall, M. L. (1987). Microbial protein and peptide metabolism in rumen fluid from faunated and ciliate free sheep. British Journal of Nutrition 58, 87-93.

Williams, A. G. (1986). Rumen holotrich ciliate protozoa. Microbiological Reviews 50, 25-49.

Williams, A. G. \& YaRLetT, N. (1982). An improved technique for the isolation of holotrich protozoa from rumen contents by differential filtration with defined aperture textiles. Journal of Applied Bacteriology 52, 267-270. 